\title{
INTERAKSI ANGGOTA KARANG TARUNA BHAKTI PERTIWI DALAM PENGEMBANGAN WISATA ANDEMAN BOONPRING DI DESA SANANKERTO KECAMATAN TUREN KABUPATEN MALANG
}

\author{
Siti Nur Azizah ${ }^{1}$, Agus Purnomo $^{1 *}$, Sukamto ${ }^{1}$ \\ ${ }^{1}$ Universitas Negeri Malang, Indonesia \\ *e-mail: agus.purnomo.fis@um.ac.id
}

\begin{abstract}
Abstrak
Karang taruna Bhakti Pertiwi memiliki kegiatan utama mengelola wisata desa dalam bentuk eko wisata. Oleh karena itu tujuan artikel ini untuk menganalisis peran anggota karang taruna Bhakti Pertiwi dalam pengembangan wisata Andeman Boonpring di desa Sanankerto kecamatan Turen kabupaten Malang. Penelitian ini menggunakan metode penelitian kualitatif dengan jenis penelitian deskriptif. Teknik pengumpulan data dalam penelitian ada tiga, yaitu wawancara, observasi, dan dokumentasi. Simpulan penelitian ini adalah dalam mengembangkan potensi wisata diperlukan kerjasama yang baik. Interaksi sangat penting untuk menjalin komunikasi yang dilakukan oleh orang perorangan untuk membangun suatu kerjasama. Karang taruna Bhakti Pertiwi dalam mengembangkan wisata Andeman Boonpring bekerjasama dengan BUMdes, Poktan, Pokdarwis dan masyarakat desa Sanankerto. Program kerja karang taruna Bhakti Pertiwi dalam pengembangan wisata antara lain spot foto, pembuatan galeri, bank sampah, penyewaan dekor, penyewaan sound system, pembuatan warung untuk relokasi pedagang. Semua itu bertujuan untuk menarik wisatawan agar berkunjung ke Andeman Boonpring.
\end{abstract}

Kata kunci: Interaksi Karang Taruna; Pengembangan Wisata; Andeman Boonpring

\begin{abstract}
Karang Taruna Bhakti Pertiwi has the main activities in managing village tourism in the form of eco-tourism. Therefore, this article aims to analyze the role of members of the youth organization Bhakti Pertiwi in tourism development Andeman Boonpring in Sanankerto village, Turen district, Malang district. This research uses qualitative research methods with descriptive research types. There are three data collection techniques in the study, namely, interviews, observation, and documentation. This study concludes that developing tourism potential requires good cooperation. Interaction is significant to establish communication made by individuals to build a partnership. Karangtaruna Bhakti Pertiwi in developing tourism Andeman Boonpring collaborated with BUMdes, Poktan, Pokdarwis, and the Sanankerto village community. The Bhakti Pertiwi cadets' work program in tourism development includes photo spots, galleries, garbage banks, decorating rentals, sound system rentals, making stalls for merchant relocation. All of that aims to attract tourists to visit Andeman Boonpring.
\end{abstract}

Keywords: Interaction of Karang Taruna; Tourism Development; Andeman Boonpring 
Siti Nur Azizah, Agus Purnomo, Sukamto | Interaksi Anggota Karang Taruna Bhakti Pertiwi Dalam Pengembangan Wisata Andeman Boonpring Di Desa Sanankerto Kecamatan Turen Kabupaten Malang

\section{PENDAHULUAN}

Karang taruna merupakan organisasi yang dilakukan oleh masyarakat di Indonesia terutama kaum muda yang berkedudukan atau tinggal di desa dan kelurahan. Interaksi sosial yang dilakukan oleh karang taruna merupakan sebuah bentuk dan juga wadah bagi upaya pembinaan dan pengembangan kesejahteraan sosial. Sebagai organisasi fungsional kepemudaan karang taruna diharapkan mampu menjadi organisasi yang kondusif dalam membantu mengembangkan desa untuk menjadi lebih menarik bahkan bisa meningkatkan roda perekonomian masyarakat sekitar. Karang taruna mempunyai tugas pokok bersama dengan pemerintah dan komponen masyarakat lainnya untuk menanggulangi berbagai masalah kesejahteraan sosial, terutama yang dihadapi generasi muda, baik yang bersifat previntif, rehabilitatif maupun pengembangan potensi generasi muda di lingkungannya (Purnomo, 2014).

Upaya dalam mengidentifikasi, memahami, mendayagunakan berbagai potensi yang dimiliki serta melakukan program semaksimal mungkin untuk mengembangkan ide-ide yang baru, hal tersebut merupakan kemandirian yang harus dimiliki oleh setiap anggota karang taruna. Seperti halnya kepedulian yang ditujukan kepada kesejahteraan masyarakat. Pemuda karang taruna seharusnya memiliki peran penting dalam proses interaksi sosial seperti menciptakan ide-ide baru yang mengikuti zaman agar kesejahteraan masyarakat bisa teratasi dengan baik. Seperti halnya pembangunan wisata lokal yaitu menjadikan salah satu ikon desa sebagai tempat wisata yang mampu menarik minat pengunjung dan membantu roda perekonomian masyarakat sekitar.

Pariwisata mulai diminati sebagai salah satu sektor yang sangat menjanjikan bagi perkembangan wilayah di skala global terutama pengembangan wisata dipedesaan. Seiring wilayah yang masih alami, yang tidak hanya mengembangkan aspek lingkungan dalam hal konservasi saja, namun juga memberikan keuntungan bagi masyarakat sekitar, sebagai salah satu upaya pengembangan pedesaan untuk meningkatkan perekonomian lokal, dimana masyarakat di kawasan tersebut merupakan pemegang kendali utama (Tanaya, 2014).

Pengembangan pariwisata pada suatu daerah selalu akan diperhitungkan dengan keuntungan dan manfaat bagi masyarakat yang ada di sekitarnya. Pengembangan pariwisata harus sesuai dengan perencanaan yang matang sehingga bermanfaat baik bagi masyarakat, baik juga dari segi ekonomi, sosial dan juga budaya. Tujuan utama dalam pengembangan pariwisata adalah untuk mengintegrasi semua aspek pengembangan wisata terhadap kehidupan sosial ekonomi. Masyarakat merupakan tujuan utama dalam sebuah pengembangan pariwisata, dengan kehidupan masyarakat lokal akan memperoleh atau merasakan berbagai manfaat antara lain dapat meningkatkan kesejahteraan, membuka lapangan pekerjaan baru, pembangunan ekonomi lokal, serta pada akhirnya akan sampai pada perkembangan wilayah (Hermawan, 2016).

Kawasan hutan bambu seluas 24 hektare ini sempat disia-siakan potensinya dan pada 1 Maret 2014 dimulailah pengembangan atau pembangunan eko wisata yang ada di desa Sanankerto, tempat wisata tersebut bernama Andeman Boonpring. Wisata ini dicetuskan oleh karang taruna Bhakti Pertiwi yang berada di desa Sanankerto, kecamatan Turen. Karang taruna Bhakti Pertiwi mengembangkan sebuah lahan yang ditumbuhi banyak bambu sebagai potensi wisata lokal yang akan diminati banyak masyarakat setempat maupun luar daerah. Visi yang tercantum dalam karang taruna 
Bhakti Pertiwi yaitu menciptakan generasi muda yang unggul dengan memperhatikan potensi-potensi disekitarnya yang dianggap dapat membantu kesejahteraan masyarakat. Oraganisasi pemuda desa atau yang biasa disebut karang taruna ini harus memiliki visi dan misi dan berpola kreativitas untuk mempermudah meraih prestasi. Perkembangan suatu sikap banyak dipengaruhi oleh lingkungan sosial dan dapat artikan jika interaksi antara seseorang dengan lingkungannya sangat mempengaruhi pengembangan kreativitas (Kurniasari, 2013). Karang taruna Bhakti Pertiwi yang dibentuk oleh para pemuda desa Sanankerto, kecamatan Turen, kabupaten Malang memiliki visi yaitu membangun generasi muda yang religius, terampil, mandiri, berprestasi serta memiliki rasa peduli yang besar terhadap sesama. Perwujudan kinerja tersebut telah dibuktikan dengan adanya pencetusan gagasan yaitu pengembangan ekowisata, memanfaatkan kekayaan alam yang ada, serta memperbarui pola tatanan wilayah sebagai daerah yang memiliki nilai tambah, dan memiliki potensi untuk menunjang kesejahteraan masyarakat.

Terkait dengan pengembangan wisata yang telah dilakukan oleh karang taruna Bhakti Pertiwi peneliti bermaksud untuk mengkaji interaksi sosial yang dilakukan oleh anggota karang taruna Bhakti Pertiwi dalam mencetuskan Wisata Andeman Boonpring dan program-program yang dilakukan karang taruna Bhakti Pertiwi dalam mengembangkann Wisata Andeman Boonpring. Karang taruna Bhakti Pertiwi memiliki program pengembangan usaha di wilayah ekowisata dan program bank sampah. Peneliti tertarik akan interaksi sosial yang dilakukan oleh karang taruna Bhakti pertiwi, dan mencoba mengkaji hal tersebut pada penelitian ini.

Pengertian Interaksi Sosial Manusia sebagai individu, akan menciptakan sebuah ruang atau wilayah pribadi, yang tidak bisa disentuh oleh pihak lain. Sementara sebagai makhluk sosial, secara instintif, manusia akan merasakan keinginan untuk menjadi bagian dari kumpulan manusia lain, dan mengadakan hubungan dengan mereka. Setiap orang mudah bergaul dengan orang lain melalui berbicara (komunikasi), bersalaman, bercanda, atau bahkan bermusuhan dan itu semua merupakan tindakan yang dinamakan interaksi sosial. Maka hal tersebut merupakan intisari sosial. Artinya, kehidupan sosial tampak secara jelas dalam berbagai cara pergaulan seseorang dengan orang lain, karena di dalam interaksi selalu terjadi kontak dan terjalin hubungan antara manusia selaku individu dengan individu lainya (Mistio, 2012).

Hubungan-hubungan sosial yang dinamis yang menyangkut hubungan antara orang-orang-perorangan, antara kelompokkelompok manusia maupun antara orang perorangan dengan kelompok manusia" (Soekanto, 2012). Interaksi sosial adalah "proses dimana antara individu dengan individu, individu dengan kelompok, atau kelompok dengan kelompok berhubungan satu dengan yang lain. (Narwoko, 2004). Dapat disimpulkan bahwa interaksi sosial merupakan kunci dari semua kehidupan sosial karena tanpa interaksi, tidak mungkin ada kehidupan bersama atau berkelompok.

Bentuk interaksi sosial dapat berupa kerja sama, persaingan, dan bahkan dapat juga berbentuk pertentangan atau pertikaian. Pertikaian mungkin akan mendapatkan suatu penyelesaian, nanun penyelesaian tersebut hanya akan dapat diterima untuk sementara waktu, yang dinamakan akomodasi (Philipus, 2006). Menurut Philipus Adapun bentuk-bentuk interaksi sosial antara lain adalah asosiatif dan disasosiatif.

Organisasi kemasyarakatan yang dapat menampung aspirasi dan melibatkan generasi muda adalah Karang Taruna. Selain menampung aspirasi, Karang Taruna juga berperan sebagai wadah penanaman rasa kebangsaan secara 
Siti Nur Azizah, Agus Purnomo, Sukamto | Interaksi Anggota Karang Taruna Bhakti Pertiwi Dalam Pengembangan Wisata Andeman Boonpring Di Desa Sanankerto Kecamatan Turen Kabupaten Malang

nasional, pengembangan potensi diri dan merupakan organisasi yang bergerak dalam bidang kesejahteraan sosial (Kawalod, 2015). Anggota karang taruna adalah para generasi muda (pemuda) yang berasal dari desa tersebut, yang memiliki ide-ide bagus dalam hal pengembangan, pemberdayaan dan solusi untuk menangani aspirasi dari masyarakat. Generasi muda atau pemuda berperan sangat penting dan utama dalam organisasi di desanya, yang dinamkan pemuda yaitu penduduk yang berusia 15- 35 tahun, mereka yang diidealkan sebagai sosok yang penuh energi, semangat, dan kreativitas untuk menciptakan semangat pembaharuan (Kawalod, 2015).

Para pemuda yang bergabung dalam suatu organisasi dalam mencapai visi dan misi organisasi karang taruna tersebut, maka diperlukan upaya dan peranan organisasi karang taruna dalam mengembangkan kreativitas generasi muda mengungkapkan bahwa dalam perkembangan suatu sikap banyak dipengaruhi oleh lingkungan sosial. Berdasarkan teori tersebut, interaksi antara seseorang dengan lingkungannya sangat mempengaruhi pengembangan kreativitas (Kurniasari, 2013). Karang Taruna secara eksplisit merupakan wadah pembinaan dan pengembangan generasi muda yang aktif dalam pembangunan nasional serta dalam bidang kesejahteraan sosial dimana Karang Taruna sebagai salah satu wadah kreativitas generasi muda yang memiliki peranan sangat penting bagi tumbuh kembangnya kegiatan yang dilakukan (Pratama, 2018).

Karang Taruna adalah suatu organisasi Kepemudaan yang ada di Indonesia dan merupakan sebuah wadah tempat pengembangan jiwa sosial generasi muda, Karang Taruna tumbuh atas kesadaran dan rasa tanggung jawab sosial dari masyarakat dan untuk masyarakat itu sendiri khususnya generasi muda yang ada di suatu wilayah desa, kelurahan atau komunitas sosial yang sederajat, terutama bergerak pada bidang-bidang kesejahteraan social (sawitri, 2014). Karang taruna pada hakekatnya adalah wadah pembinaan dan pengembangan generasi muda demi terwujudnya kesejahteraan generasi muda. Karang Taruna mengemban misi tulus, ikhlas dan penuh rasa manusiawi dalam upaya mengatasi segala bentuk permasalahan generasi muda. Sehingga peranan karang taruna senantiasa dibutuhkan kapanpun, di manapun demi terwujudnya masa depan yang lebih cerah bagi generasi muda, bangsa dan negara dan seluruh masyarakat Indonesia. Berpedoman pada pengertian di atas maka Karang taruna, yaitu: a) Wadah pembinaan dan pengembangan generasi muda. b) Tumbuh atas kesadaran dan rasa tanggung jawab sosial. c) Bergerak terutama dalam bidang kesejahteraan sosial. d) Secara fungsional dibina dan dikembangkan oleh Departemen Sosial. Karang Taruna berkedudukan di desa/kelurahan yang anggotanya berusia 17-40 tahun dengan sistem keanggotaan menganut stelsel pasif, dalam arti seluruh generasi muda dalam lingkungan desa/kelurahan adalah anggota karang taruna yang selanjutnya disebut warga Karang Taruna, namun ada yang aktif dan ada yang pasif. Semua anggota karang taruna memiliki hak dan kewajiban yang sama tanpa membedakan asal keturunan, suku, jenis kelamin, kedudukan sosial dan Agama (Arif, 2014).

Karang Taruna adalah organisasi sosial kemasyarakatan yang berfungsi sebagai wadah dan sarana pengembangan setiap anggota masyarakat yang tumbuh dan berkembang atas dasar kesadaran dan tanggung jawab sosial dari, oleh, dan untuk masyarakat terutama generasi muda di wilayah desa atau kelurahan atau nama lain yang sejenis terutama bergerak di bidang penyelenggaraan kesejahteraan sosial (Widodo, 2017). Saragi juga berpendapat jika Karang Taruna 
Siti Nur Azizah, Agus Purnomo, Sukamto | Interaksi Anggota Karang Taruna Bhakti Pertiwi Dalam Pengembangan Wisata Andeman Boonpring Di Desa Sanankerto Kecamatan Turen Kabupaten Malang

merupakan organisasi kepemudaan nonpolitis kerena faktor-faktor yang bersifat pribadi tidak memegang peranan penting dalam pengambilan keputusan. Organisasi sukarela tumbuh dan berkembang atas kesadaran bersama. Sebagai organisasi sosial kepemudaan yang memiliki jaringan hingga ke tingkat bawah (Widodo, 2017).

Karang taruna merupakan salah satu organisasi pemuda yang tidak asing lagi karena merupakan wadah yang telah memiliki misi untuk membina generasi muda khususnya di pedesaan. Adapun visi karang taruna yaitu sebagai wadah pembinaan dan pengembangan kreativitas generasi muda yang berkelanjutan untuk menjalin persaudaraan dan rasa kebersamaan menjadi mitra organisasi lembaga, baik kepemudaan ataupun pemerintah dalam pengembangan kreativitas. Kemampuan dibidang kesejahteraan sosial baik untuk masyarakat dilingkungan sekitar ataupun di wilayah lain. Dalam bidang kesejahteraan sosial, karang taruna sebagai organisasi sosial masyarakat di pedesaan akan ditingkatkan fungsi dan perannya agar dapat menghimpun menggerakkan dan menyalurkan peran serta generasi muda dalam pembangunan. Selain mewujudkan kesejahteraan sosial di desa atau kelurahan, karang taruna berfungsi mengembangkan potensi kreatifitas generasi muda agar secara terarah generasi muda di pedesaan membina dirinya sebagai pendukung pembangunan pedesaan (Arif, 2014).

\section{METODE}

Penelitian yang berjudul Interaksi Sosial Anggota Karang Taruna Bhakti Pertiwi Dalam Pengembangan Wisata Andeman Boonpring di Desa Sanankerto Kecamatan Turen Kabupaten Malang menggunakan pendekatan kualitatif, sifat data yang dikumpulkan adalah berupa data deskriptif karena peneliti bermaksud mendeskripsikan, menguraikan dan menggambarkan interaksi sosial yang dilakukan oleh para pemuda yaitu anggota organisasi karang taruna Bhakti Pertiwi di Desa Sanankerto Kecamatan Turen Kabupaten Malang yang memiliki peran dalam pengembangan ekowisata yang bernama Andeman Boonpring.

Metode kualitatif sebagai prosedur penelitian yang menghasilkan data deskriptif berupa kata-kata tertulis atau lisan dari orang-orang dan perilaku yang diamati. Dalam penelitian kualitatif data yang diperoleh berupa informasi, keterangan dan berupa hasil-hasil pengamatan. Penelitian kualitatif hasil pengamatan tidak disajikan dalam bentuk numerik, melainkan dalam bentuk kata-kata sesuai dengan karakteristik dari pendekatan kualitatif hingga diperoleh pemahaman-pemahaman yang lebih mendalam dan lebih luas tentang pengamatan dibalik informasi selama berinteraksi di lapangan (Moleong, 2004). Metode kualitatif juga disebut sebagai tradisi tertentu pada sebuah ilmu pengetahuan social yang secara fundamental bergantung pada pengamatan pada manusia dan berhubungan dengan orang-orang dalam bahasanya dan peristilahannya (Rahmat, 2009).

Penelitian yang dilakukan berupaya mendeskripsikan secara jelas mengenai interaksi sosial anggota organisasi karang taruna Bhakti Pertiwi di desa Sanankerto dalam mengembangkan potensi desa untuk dijadikan sebuah wisata yang dapat menarik minat pengunjung dan membantu perekonomian masyarakat setempat. Oleh karena itu penelitian kualitatif ini tidak diwujudkan dengan angka-angka, sehingga hasil penelitian yang penulis lakukan dapat dipertanggungjawabkan serta dapat digunakan untuk menjawab masalah yang akan diteliti.

\section{Kehadiran Peneliti}

Kehadiran peneliti dalam penggunaan penelitian kualitatif sangat Jurnal IImu Sosial dan Humaniora | 234 
penting, karena peneliti merangkap pekerjaan yaitu perencanaan, pelaksanaan pengumpulan data, analisis, penafsiran data, dan akhirnya melaporkan hasil penelitiannya itu" (Moleong, 2004). Penelitian ini mengharuskan peneliti terjun langsung ke lapangan, maka langkahlangkah yang digunakan peneliti agar penelitian dapat berjalan dengan baik adalah: (1) peneliti mendatangi Balai Desa Sanankerto untuk menemui para anggota karang taruna Bhakti Pertiwi dan melakukan wawancara tentang penelitian terkait, dan (2) peneliti mendatangi tempat wisata Andeman Boonpring bersama anggota karang taruna Bhakti Pertiwi untuk meninjau secara langsung dan tahap-tahap proses pengembangan wisata tersebut.

\section{Lokasi Penelitian}

Lokasi penelitian membawa peranan penting dalam melakukan penelitian, karena lokasi penelitian adalah lokasi dimana penelitian itu dilakukan. Lokasi penelitian harus dijelaskan secara rinci agar memudahkan penulis lain atau pengamat lain untuk mengetahui dengan jelas dimana penelitian ini dilakukan karena lokasi penelitian memiliki peranan penting untuk mendukung keberhasilan sebuah penelitian. Penelitian ini dilakukan di desa Sanankerto kecamatan Turen, kabupaten Malang dan secara khusus dilakukan di wilayah ekowisata Andeman Boonpring.

\section{Sumber Data}

Sumber data utama dalam penelitian kualitatif adalah kata-kata dan tindakan selebihnya data tambahan seperti dokumen dan lain-lain" (Moleong, 2004). Dalam hal ini yang dimaksud data adalah sesuatu mengenai informasi atau keterangan yang dapat berupa fakta dan yang ada kaitannya dan mendukung suatu penelitian yang berhubungan dengan interaksi sosial sebagai proses para anggota Karang Taruna Bhakti Pertiwi dalam pengembangan wisata Andeman Boonpring di Desa Sanankerto. Data utama yang diperoleh dari informan adalah melalui wawancara dan melalui pengamatan dilapangan". Informan yang digunakan dalam penelitian ini terbagi menjadi dua yakni informan pendukung dan informan kunci. Pemilihan informan dengan menggunakan teknik purposive. Teknik purposive adalah teknik pengambilan data pada penelitian dengan adanya pertimbangan. Pertimbangan tersebut misalnya orang yang dianggap tahu apa yang peneliti harapkan, atau mungkin dia mengetahui secara luas objek yang akan diteliti sehingga akan memudahkan peneliti dalam melakukan penelitian (Hasan, 2008). Dalam hal ini data diperoleh melalui pihakpihak yaitu kepala desa, anggota karang taruna bhakti pertiwi dan masyarakat yang terlibat dalam pengembangan potensi desa yaitu terciptanya Andeman Boonpring di desa Sanankerto.

\section{Teknik Pengumpulan Data}

Teknik pengumpulan data merupakan langkah yang paling strategis dalam penelitian, karena tujuan dari penelitian adalah mendapatkan data. Tanpa mengetahui teknik pengumpulan data, peneliti tidak akan mendapatkan data yang memenuhi standar data yang ditetapkan (Sugiyono, 2010). Teknik pengumpulan data agar mendapatkan data yang relevan dan akurat, peneliti bertindak sebagai instrumen sekaligus sebagai pengumpul data. Teknik pengumpulan data yang dipakai dalam penelitian ini yaitu dilakukan dengan cara 1) Obervasi, 2) Wawancara, 3) Pencatatan, dan 4) Dokumentasi.

Obeservasi dalam hal ini peneliti terlibat dalam kegiatan orang yang sedang diamati atau kegiatan yang digunakan sebagai sumber penelitian. Peneliti sekaligus mendapatkan data berupa dokumentasi (foto, rekaman audio/video) dan beberapa data konkret yang dapat dijadikan pelengkap data dalam penelitian 
ini. Dokumentasi berupa foto lokasi sebelum dibangunnya ekowisata, dan sesudah dibangunnya ekowisata. Ada juga beberapa foto kegiatan di saat pembangunan wisata tersebut dimulai secara bertahap. Dan data audio berupa hasil wawancara dengan narasumber. Obeservasi juga dilakukan pada tahap awal, yaitu sebagai persiapan dalam menentukan data dan kelengkapan penelitian yang diperlukan. Pada tahap ini dilakukan peninjauan secara cermat dan tepat, agar penelitian dapat berjalan dengan baik dan data yang diperoleh didapat dengan mudah dan konkret.

Wawancara adalah percakapan dengan maksud tertentu yang dilakukan oleh dua pihak yaitu pewawancara (interviewer) yang mengajukan pertanyaan dan terwawancara (interviewee) yang memberikan jawaban atas pertanyaan itu (Moleong, 2004). Wawancara dilakukan denga pihak - pihak yang terkait yaitu kepala desa, anggota karang taruna Bhakti pertiwi dan juga masyarakat setempat. Adapun informan yang akan diwawancari adalah: (1) Anggota karang taruna Bhakti Pertiwi (2) Kepala desa Sanankerto, kecamatan Turen, kabupaten Malang, dan (3) Masyarakat pihak pengelola tempat wisata Andeman Boonpring di desa Sanankerto, kecamatan Turen, kabupaten Malang.

Untuk memperlancar jalannya wawancara, peneliti menyiapkan instrumen berupa pedoman wawancara. Pedoman wawancara disiapkan dengan berisi pertanyaan-pertanyaan semi terstruktur dengan maksud pertanyaan-pertanyaan tersebut masih memberikan peluang kepada sumber data dalam memberi pendapat-pendapatnya terkait dengan objek yang diteliti.

Pencatatan digunakan peneliti untuk mendapatkan informasi yang lebih terstruktur. Teknik pengumpulan data (pencatatan) oleh peneliti dengan kejadian dan urutan kejadiannya sebagaimana yang terjadi pada situasi nyata. Pencatatan mencakup apapun yang tampak relevan bagi peneliti. Pencatatan merupakan hasil dari penelitian yang dimana sebagai proses kelengkapan data dalam penelitian, pecatatan dilakukan pada beberapa pertanyaan untuk narasumber yang ditujukan sebagai pelengkap data penelitian.

Teknik dokumentasi dilakukan untuk melengkapi data atau informasi yang dikumpulkan dari hasil observasi maupun wawancara, data atau informasi yang dikumpulkan dari bahan-bahan dokumentasi yang ada dilapangan dapat dijadikan bahan dalam pengecekan keabsahan data. Dokumentasi berupa foto lokasi sebelum dibangunnya ekowisata, dan sesudah dibangunnya ekowisata. Ada juga beberapa foto kegiatan di saat pembangunan wisata tersebut dimulai secara bertahap. Data audio berupa hasil wawancara dengan narasumber.

\section{Teknik Analisis Data}

Data yang telah terkumpul kemudian dianalisis lebih lanjut agar dapat menjawab rumusan masalah yang telah dibentuk, data yang dikumpulkan melalui penelitian ini dikelompokkan menjadi dua bagian yaitu data utama dan data pendukung. Data utama diperoleh melalui subjek penelitian, yaitu orang-orang yang terlibat langsung dalam kegiatan sebagai fokus penelitian. Sedangkan data pendukung bersumber dari dokumen-dokumen berupa catatan, rekaman, gambar, atau foto serta bahanbahan lain yang dapat mendukung penelitian ini. Sumber data utama dalam penelitian kualitatif ialah dalam bentuk katakata atau ucapan dari perilaku orang-orang yang diamati dalam penelitian ini mengunakan metode observasi, wawancara dan dokumentasi yang diperoleh dari ketua karang taruna serta pengurus lainnya.Berisi bagaim ana data dikumpulkan, sumber data dan cara analisis data 
Siti Nur Azizah, Agus Purnomo, Sukamto | Interaksi Anggota Karang Taruna Bhakti Pertiwi Dalam Pengembangan Wisata Andeman Boonpring Di Desa Sanankerto Kecamatan Turen Kabupaten Malang

\section{HASIL DAN PEMBAHASAN}

Interaksi yang berlangsung selama kurun waktu tertentu akan membuat individu bisa menyesuaikan dirinya dengan individu atau kelompok lain. Penyesuaian ini akan membentuk sikap saling terbuka antar individu dan memudahkan komunikasi yang dilakukan. Karang Taruna mejalin interaksi yang melibatkan pengurus, anggota, dan BUMdes. Interaksi yang dilakukan tidak hanya pada saat formal seperti rapat, tetapi pada keseharian para pengurus dan anggota di Desa Sanankerto.

Interaksi sosial merupakan hubungan yang dinamis, menyangkut hubungan antara individu, antar kelompok maupun individu dengan kelompok baik seacara langsung atau tidak langsung (Soekanto, 2012). Rutinitas pertemuan anggota Karngtaruna dalam rapat atau diskusi dimaksudkan untuk meningkatkan pengembangan desa wisata dalam mensejahteraan ekonomi masyarakat sekitar. Seiring berkembangnya waktu, anggota karang taruna sudah mulai terbiasa dan bisa menyesuaikan diri ke dalam lingkungannya sehingga mereka mulai dapat melakukan proses interaksi dan bekerja sama dengan anggota yang lainnya. Aggota karang taruna dapat menjalin interaksi dan kerjasama melalui adanya rapat, diskusi dan sosoalisasi yang diadakan selama 1 minggu sekali. Menurut mereka hal tersebut penting dilakukan karena tidak semua anggota karang taruna berpengalaman pada bidang yang diperlukan dalam pengembangan wisata Andeman Boonpring dan melaui kegiatan rapat rutin mereka juga bisa merencanakan inovasi-inovasi dalam berlangsungnya pengembangan wisata Andeman Boonpring (Gmabar 1). Perencanaan yaitu tahap di mana masyarakat mengikuti pertemuan/rapat dan berkonsultasi dengan pihak pengurus pariwisata dan tokoh masyarakat, memberikan informasi dengan identifikasi potensi dan permasalahan (Munawaroh, 2017).

Semua unsur yang ada dalam Karang taruna terlibat dalam pelaksanaan pengembangan wisata Andeman Boonpring. Kegiatan pelaksanaan diwujudkan dengan bentuk keterlibatan masyarakat dalam menyediakan berbagai fasilitas pendukung yang bisa memenuhi kebutuhan para wisatawan selama berada di destinasi wisata (Andriyani, 2017; Purnomo \& Aristin, 2016). Kegaiatan tersebut merupakan rencana yang sudah dipikirkan oleh Karang Taruna Bhakti Pertiwi beserta pemerintah Desa agar wisata Andeman Boonpring semakin memiliki keunggulan dibandingkan dengan wisata yang ada di Desa lainnya sehingga tetap diminati oleh para wisatawan. Dinamika pengembangan sarana wisata yang ada di Boon Pring Andeman seperti terlihat pada Gambar 1.

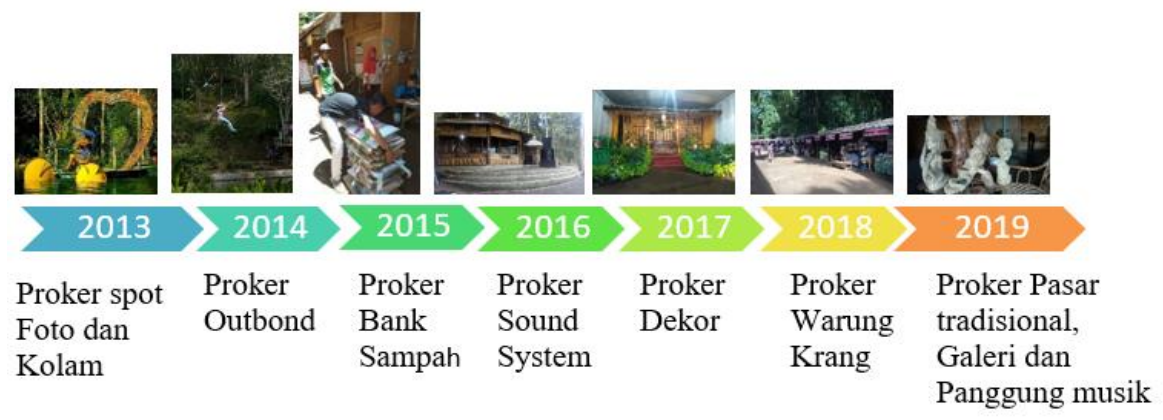

Gambar 1. Pengembangan sarana penunjang wisata Boon Pring Andeman mulai 2013-2019 
Berdasarkan dari temuan maka analisis tentang karakteristik anggota Karang Taruna Bhakti Pertiwi berbeda-beda. Dilihat dari segi usia anggota Karang Taruna memiliki rentang usia 19-25 tahun. Pekerjaanya bermacam-macam, ada yang menajdi pelajar, mahasiswa, wirausaha, dan wiraswasta. Dari berbagai karakteristik tersebut, anggota Karang Taruna memiliki peran sesuai dengan tuganya masingmasing.

Peran Karang Taruna secara umum dalam setiap kegiatan pengembangan wisata Andeman Boonpring, seperti mengelola, menjaga, merawat dan memperbaiki sarana dan prasarana. Karang Taruna juga berperan sebagai wadah penanaman rasa kebangsaan secara nasional, pengembangan potensi diri dan merupakan organisasi yang bergerak dalam bidang kesejahteraan sosial (Kawalod, 2015). Peran Karang Taruna untuk memudahkan dalam pengembangan wisata Andeman Boonpring ini meliputi tiga tahap, yaitu perencanaan, pelaksanaan, dan evaluasi. Pada tahap perencanaan ini terlihat dalam keikutsertaan rapat, diskusi, dan sosialisasi untuk membahas program kerja yang sudah di sepakati bersama. Program tersebut antara lain (1) Pembuatan warung-warung di sekitar taman wisata, tujuannya juga untuk meningkatkan ekonomi masyarakat sekitar. (2) Menambahkan wahana baru seperti outbound yang bertujuan untuk menarik wiasatawan atau pelajar dalam meningkatkan kegiatan di wisata Andeman Boonpring. (3) Bikin pasar tradisional, pasar tradisonal ini nantinya melibatkan seluruh masyarakat di Desa Sanankerto melalui Perwakilan RT, diharapkan dari pasar trasional ini juga meningkatkan ekonomi masyarakat Desa Sanankerto dan menjadi daya tarik bagi wisatawan.

Interaksi sosial Karang Taruna Bhakti Pertiwi yang terjadi dapat diketahui melalui dua tahapan yaitu asosiatif dan disosiatif.
Pada tahap asosiatif anggota Karang Taruna bekerja sama dengan masyarakat sekitar untuk mengembangkan wisata Andeman Boonpring. Mereka mempunyai kesadaran dalam dirinya karena melihat potensi alam yang dimiliki oleh Desa Sanankerto sehingga menumbuhkan niat dari masing-masing anggota untuk mengembangkan wisata Andeman Boonpring. Anggota Karang Taruna dapat berinteraksi dan bekerja sama melalui adanya rapat diskusi yang diadakan. Pada tahap disosiatif Karang Taruna menemukan beberapa hambatan yang dialami yaitu ketika mengadakan rapat atau diskusi tidak semua anggota bisa hadir. Hasil yang sudah disepakati dalam rapat atau diskusi oleh beberapa anggota yaitu mengelola dan mengembangkan wisata Andeman Boonpring, perbaikan sarana dan prasarana, promosi wisata.

\section{SIMPULAN DAN SARAN}

Berdasarkan pembahasan yang sudah dipaparkan sebelumnya, maka dapat disimpulkan bahwa sejarah awal terbentuknya wisata Andeman Boonpring ini dimulai sejak tahun 2013 namun belum terealisasikan karena karangtaruna yang Sananku ini bubar. Pada tahun 2014 wisata Andeman boonpring ini di realisasikan dengan karang taruna yang baru yaitu Bhakti Pertiwi. Tujuan dibentuknya wisata Andeman Boonpring ini adalah: (1) untuk meningkatkan pendapatan daerah dan masyarakat sekita, (2) untuk memanfaatkan dan melestarikan potensi wisata. Pembentukan wisata Andeman Boonpring ini juga melibatkan karang taruna, pokdarwis, dan BUMdes. Wisata Andeman Boonpring ini diresmikan dengan bupati Malang pada saat itu oleh Bapak H. Rendra Kresna tepatnya April tahun 2015. Terdapat beberapa pihak yang ikut serta mendukung dalam pembentukan wisata Andeman Boonpring, seperti, BUMdes, Pokdarwis, Poktan, Pemerintah desa dan masyarakat 
Siti Nur Azizah, Agus Purnomo, Sukamto | Interaksi Anggota Karang Taruna Bhakti Pertiwi Dalam Pengembangan Wisata Andeman Boonpring Di Desa Sanankerto Kecamatan Turen Kabupaten Malang

Desa Sanankerto, akan tetapi yang menjadi pengelola utama dalam pengembangan wisata Andeman Boonpring adalah masyarakat dan pemuda yang tergabung dalam Karang Taruna Bhakti Pertiwi.

Saran bagi peneliti selanjutnya, sebaiknya informasi dan wawasan tentang pengembangan wisata pada penelitian ini dapat dijadikan sebagai referensi dalam melakukan penelitian terkait pengembangan wisata dengan konsep penelitian yang berbeda. Pemerintahan Desa Sanankerto hendaknya tetap selalu fokus untuk mengembangkan wisata Andeman Boonpring, selalu mendukung kegiatan yang dilakukan oleh karang taruna Bhakti Pertiwi dalam mengembangkan wisata Andeman Boonpring, dan ikut serta dalam menjaga, mengelola dan memfasilitasi wisata Andeman Boonpring dalam bentuk pemberian dana dan sosialisasi untuk pengembangan wisata Andeman Boonpring. Saran bagi anggota karang taruna Bhakti Pertiwi hendaknya lebih aktif lagi dalam melibatkan dirinya dalam pengembangan wisata Andeman Boonpring di Desa Sanankerto. Kemudian hendaknya selalu terus memunculkan ide atau inovasi-inovasi baru agar pengunjung tetap tertarik untuk berkunjung ke wisata Andeman Boonpring.

\section{DAFTAR PUSTAKA}

Andriyani, I. A. A., 2017. Pemberdayaan Masyarakat Melalui Pengembangan Desa Wisata dan Implikasinya Terhadap Ketahanan Sosial Budaya Wilayah (Studi Di Desa Wisata Penglipuran Bali). Jurnal Ketahanan Sosial.

Arif, R. M., 2014. Peran Karang Taruna dalam Pembinaan Remaja Di Dusun Candi Desa Candinegoro Kecamatan Wonoayu Kabupaten Sidoarjo. Jurnal Kajian Moral Dan Kewarganegaraan.
Hasan, M. T., 2008. Metodologi Penelitian Kualitatif. malang: visipress.

Hermawan, H., $2016 . \quad$ Dampak Pengembangan Desa Wisata Nglanggeran Terhadap Ekonomi Masyarakat Lokal. Jurnal Pariwisata.

Kawalod, A. F., 2015. Peranan Organisasi Karang Taruna dalam Pemberdayaan Masyarakat Desa (Suatu Studi Di Desa Tewasen, Desa Pondos, Desa Elusan, Desa Wakan Kecamatan Amurang Barat Kabupaten Minahasa Selatan). Jurnal Administrasi Publik.

Kurniasari, D., 2013. Peranan Organisasi Karang Taruna dalam Mengembangkan Kreativitas Generasi Muda Di Desa Ngembalrejo. Semarang. Unnes Civic Education Journal.

Mistio, F., 2012. Hubungan Antara Kemampuan Berinteraksi Sosial dengan Hasil Belajar. Jurnal IImiah Konseling.

Moleong, I. j., 2004. Metodologi Penelitian Kualitatif. Bandung: Remaja rosdakarya.

Munawaroh, M., 2017. Implementasi Pembangunan Desa Wisata Batik Desa Babagan Kecamatan Lasem Kabupaten Rembang. Jurnal Pendidikan Dan Pemberdayaan Masyarakat.

Narwoko, D. J., 2004. Sosiologi Teks Pengantar dan Terapan. Jakarta: Kencana.

Philipus, 2006. Sosiologi dan Politik. jakarta: pt gafindo persada.

Pratama, F. F., 2018. Peran karang taruna dalam mewujudkan tanggung jawab sosial pemuda sebagai gerakan warga negara. Jurnal Media Kajian Kewarganegaraan.

Purnomo, A. \& Aristin, N. F., 2016. Community Based Tourism Development for Sustainable Livelihoods in Lumajang-Malang Regency East Java. Jakarta, LIPI.

Purnomo, A. D., 2014. Peranan Pengurus Karang Taruna Meningkatkan (Studi 
Siti Nur Azizah, Agus Purnomo, Sukamto | Interaksi Anggota Karang Taruna Bhakti Pertiwi Dalam Pengembangan Wisata Andeman Boonpring Di Desa Sanankerto Kecamatan Turen Kabupaten Malang

Pada Organisasi Karang Taruna Di Dusun Sawahan Desa Pendowoharjo Kecamatan Sewon Kabupaten Bantul. E-Journal Student UNY.

Purnomo, A., Ruja, I. N. \& Irawan, L. Y., 2017. Typology of Tourist Bromo Tengger Semeru National Park as a Basic Planning Integrated Tourism Design. Bandung, IOP Conf. Series: Earth and Environmental Science.

Rahmat, S. P., 2009. Penelitian Kualitatif. Jurnal Equilibrium.

Sawitri, n., 2014. Partisipasi Pemuda dalam Program Karang Taruna Desa (Studi Pada Pemuda Di Dusun Kupang Kidul Desa Kupang Kecamatan Ambarawa).. Journal of non formal education and community empowerment.

Soekanto, S., 2012. Sosiologi Suatu Pengantar. Jakarta: Raja Grafindo Persada.

Sugiyono, 2010. Memahami Penelitian Kualitatif. bandung: alfabeta.

Tanaya, R. D., $2014 . \quad$ Potensi Pengembangan Ekowisata Berbasis Masyarakat Di Kawasan Rawa Pening, Kabupaten Semarang. Jurnal Teknik $P W K$.

Widodo, A., 2017. Kesadaran 'Karang Taruna' dalam Melakukan Intervensi Komunitas Program Pemberdayaan 'Sedekah Pohon Pisang' Di Desa Gandri, Lampung Selatan. Jurnal Pemberdayaan Masyarakat. 